\title{
Array-based Comparative Genomic Hybridization (aCGH) Reveals Chromosomal Aberrations in Chronic Obstructive Pulmonary Disease (COPD): A Preliminary Study
}

\author{
Anjali Trivedi, Debabrata Ghosh, Geetanjali Bade, Randeep Guleria, \\ Meghashree Sampath, and Anjana Talwar
}

\section{ABSTRACT}

Chronic Obstructive Pulmonary Disease (COPD) is a complex disease with varying susceptibility. COPD development may be associated with copy number variation $(\mathrm{CNV})$ in susceptible genomic regions. CNV also contributes to COPD heritability as these can cause changes in DNA fragment. CNVs in COPD smokers and COPD ex-smokers have not been examined so far. Thus, genome-wide array based comparative genomic hybridization ( $\mathrm{ACGH})$ was performed in COPD $(n=15)$ and control subjects $(n=13)$ to identify the vulnerable candidate genes for genetic susceptibility and CNVs in smoker $(n=6)$ and ex-smoker $(n=9)$ COPD and compare it with control subjects to identify the candidate genes potentially involved in the pathogenesis of COPD. Copy number gains and losses were detected in several chromosomal regions.

Chromosomal regions found to be consistently associated with both subgroups of COPD, as well as, of control group were: 2 p11.2, 4q13.2, 8p23.1, 8p11.22, 12p13.31 and 14q32.33. Chromosomal regions associated with COPD were 11p15.5, 15q11.1-q11.2 and Xq28, which had several genes, (viz., CHECK2P2, HERC2P3, GOLGA6L6 and GOLGA8CP) which were associated with COPD smokers, while several other genes (viz., LICAM, LCA10, AVPR2, GDI1, HOTS and H19) were found to be associated with COPD ex-smokers. These loci and genes may be explored further for their potential use as predictive markers and better understanding of pathophysiology of COPD.

Keywords: aCGH, CNV, loss, deletion, gain, amplification.
Published Online: February 5, 2021

ISSN: $2593-8339$

DOI: $10.24018 /$ ejmed.2021.3.1.550

\section{Dr. Anjali Trivedi}

Departments of Physiology, All India Institute of Medical Sciences, New Delhi, India.

(e-mail: anjali.trivedi12@gmail.com)

Professor Debabrata Ghosh

Departments of Physiology, All India Institute of Medical Sciences, New Delhi, India.

(e-mail: debabrata.ghosh1@gmail.com) Dr. Geetanjali Bade Assistant Professor

Departments of Physiology, All India Institute of Medical Sciences, New Delhi, India.

(e-mail: geetanjalibade@gmail.com)

Professor Randeep Guleria

Director (AIIMS, New Delhi)

Department of Pulmonary, Critical Care and Sleep Medicine, All India Institute of Medical Sciences, New Delhi, India.

(e-mail: randeepg@ ${ }^{\circledR}$ hotmail.com)

Meghashree Sampath

Departments of Physiology, All India Institute of Medical Sciences, New Delhi,

(e-mail: meghashree90@gmail.com)

Professor Anjana Talwar*

Departments of Physiology, All India Institute of Medical Sciences, New Delhi, India.

(e-mail: anjanatalwar@gmail.com)

*Corresponding Author

\section{INTRODUCTION}

Chronic obstructive pulmonary disease (COPD) is a chronic respiratory disorder characterised by an obstructive ventilation pattern. COPD is rarely reversible and can lead to chronic respiratory failure [1]. From 1990 to 2015 the prevalence of COPD has increased by about $44 \%$, and more than 3 million people died from COPD world-wide in 2015, an increase by about $12 \%$ compared with 1990 data [2]. The primary cause of COPD is exposure to tobacco smoke either directly by active smoking or indirectly via exposure to second-hand smoke. Other risk factors include exposure to indoor and outdoor air pollution, occupational dusts and fumes [3], [4]. Even though cigarette smoking is the major known environmental risk factor for COPD, a large proportion of patients with COPD worldwide are nonsmokers [5] suggesting that other factors like genetic and other environmental factors also play important role in the etiopathogenesis of COPD. Epidemiological data indeed indicate potential role of genetic factors as it is observed that COPD cases aggregate in families [6]-[8]. Li et al. [9] have observed increased prevalence of chronic bronchitis in 
offspring when one or more parents were affected by the same disease. Also, severe alpha-1-antitrypsin (ATT) deficiency is a known risk factor for the development of COPD [10]. Furthermore, SERPINA1 gene at chromosome $14 q 32.13$ which encodes for AAT, was the first gene identified to be associated with COPD [11]. Larson et al. have demonstrated significantly increased prevalence of abnormal pulmonary function in siblings and children of COPD patients as compared to their spouses and it was not associated with AAT deficiency [6]. This provides further evidence that genetic factors play an important role in development of COPD which may be independent of AAT deficiency. This notion was further supported by segregation analysis reported by Givelber et al. They have provided a general model suggesting that environmental and/or polygenic genetic influences determine pulmonary function [12]. Thus, the genetic background of COPD is composed of several genes with small but constitutional effects, rather than a single major gene [8].

Completion of human genome project allowed for increased recognition of single nucleotide polymorphism (SNP) as a possible cause for phenotypic variability in the human population. Also, several population-based studies have identified the role of different SNPs in increasing susceptibility to common diseases like diabetes mellitus, macular degeneration, asthma and cancer [13]. With advancement of techniques over the past decade, researchers have however observed that human genome contains multiple regions of intermediate size copy number changes either in form of gains or losses, which are collectively called as copy number variants (CNVs). CNVs are defined as stretches of DNA larger than 1000 base pairs (bp) that are normally found only once on each chromosome in each person, but in some individuals these are duplicated or triplicated, i.e., there is a variation in the number of copies of this section of DNA from one individual to another [14]. CNVs can be germline inherited and present in a parent or can be somatic and newly acquired [15]. CNVs, either inherited from parents or new acquired, are increasingly being found to be associated with risk for various diseases as they involve thousands of bases which may affect functional DNA sequences [16]. Since CNVs can cause changes in large DNA fragment, it can affect multiple genes as compared to single base modification in SNPs and may contribute to COPD development [13]. It is possible that enrichment of currently known CNVs as environmental sensor genes may help to perceive and interact successfully with changing environment. These genes include immune and inflammatory response genes, cell signalling and cell adhesion molecules, structural proteins and ion channels $[17,18]$. The currently established gold standard for CNV detection is aCGH. [19]. This technique uses two genomes, a test and a control genome which are differentially labelled and used as probes that are cohybridized competitively onto nucleic acid targets [20]. aCGH allows for genome-wide screening for chromosomal abberations and thus it circumvents many limitations in conventional cytogenetic analysis which is limited to specific loci and hence likely to miss the information of entire genome [21]. Additionally, aCGH offers the advantage of high resolution and high throughput even without the prior knowledge of the region under investigation [22], [23]. CNV analysis has led to a significant increase in the detection of chromosomal abnormalities and is now used in clinical diagnosis [24]. The findings obtained from CNV analysis are used for clinical management, genetic counselling and for prenatal decision making. CGH array has greater sensitivity to detect small differences in copy number and aCGH studies have been performed to identify CNVs in various complex diseases such as lung cancer, emphysema, autism, neuro degenerative and neuropsychiatric disorders [24], [25].

COPD is a complex disease with varying susceptibility in the general population. Thus it becomes imperative to identify molecular markers of disease susceptibility and progression. Choi et al. analysed the chromosomal aberrations using aCGH in patients with emphysema to identify the potential candidate genes that might be causally involved in the pathogenesis of emphysema [26]. In this study, several frequently altered loci which included a gain at 5 p15.33 (60\% of the study subjects), and a loss at $7 \mathrm{q} 22.1$ (31\% of the study subjects) [26]. To our knowledge studies investigating detection and mapping of CNVs and their correlation with the disease phenotype in COPD patients are lacking. The aim of the present study was to carry out genome-wide aCGH to study the genomic aberration and CNVs in smoker COPD and ex-smoker COPD patients and compare it with control subjects to identify the candidate genes potentially involved in the pathogenesis of COPD.

\section{MATERIALS AND METHODS}

\section{A. General}

COPD patients $(n=15)$ aged 30-70 years were recruited from the Department of Pulmonary, Critical Care and Sleep Medicine, All India Institute of Medical Sciences (AIIMS), New Delhi. COPD patients comprised of COPD smokers $(n=6)$ and COPD ex-smokers $(n=9)$ having a smoking history of more than 10 pack-years. Patients who ceased smoking for more than 1 year were considered as ex-smokers. Stable COPD patients (stages 2 and 3 according to the GOLD guidelines) with an evidence of airflow limitation on spirometry $\mathrm{FEV}_{1} / \mathrm{FVC}$ ratio of $<70 \%$ were included in the present study. Control subjects $(n=13)$ comprised of Control Never Smokers $(n=8)$ and Control Smokers $(n=5)$ were also recruited. Patients who had either suffered from exacerbation, or taken steroids, or a history of any active inflammatory disease, or lung disorder besides COPD were excluded from the study. Written informed consent was obtained from all patients. The study was approved by the Institute Ethics Committee (Ref. No. IESC/T148/04.04.2014, OT-2/29.08.2016).

\section{B. Sample Collection and Processing}

$5 \mathrm{~mL}$ of blood was obtained from the volunteers and DNA was isolated from whole blood by using QIAamp DNA Mini Kit (Cat\# 51304, Qiagen, Cologne, Germany) according to the manufacturer's instructions (https://www.dnagenotek.com/US/pdf/PD-PR-00835.pdf). Extracted DNA yield was checked for protein, carbohydrates and organic solvent contamination using spectrophotometric (A260/A280 and A260/A230) quantification using Nanodrop (Thermo Fisher Scientific, MA, USA.). Total 
concentration and quality were checked with A260/A280 ratio by Nanodrop (Thermo Fisher Scientific, MA, USA).

\section{Array Comparative Genomic Hybridization (aCGH)}

Array CGH was performed using a high resolution 60-mer oligonucleotide based human whole genome CGH+SNP microarray kit (4×180 K Sureprint G3ISCA; Cat\# G4890A) obtained from Agilent Technologies, Santa Clara, USA) and using a "two-color" protocol to measure DNA copy number changes in an experimental sample relative to a same sex reference sample obtained from the manufacturer (Euro Reference, Agilent Technologies, Santa Clara, CA) [27]. All array experiments were performed according to the protocol provided by the manufacturer. DNA test and a reference of the same sex; both at the concentration of $500 \mathrm{ng}$, were double digested with RsaI and AluI for $2 \mathrm{~h}$ at $37{ }^{\circ} \mathrm{C}$. Heat inactivation of the enzymes at $65{ }^{\circ} \mathrm{C}$ was carried out for 20 min and after this step, each digested sample was labelled by random priming by using the genomic DNA Enzymatic Labelling Kit (Agilent Technologies, Santa Clara, CA) for 2 hours using Cy5-dUTP for patient DNAs and Cy3-dUTP for reference DNAs (Smith et al 2007). Column purification of the labeled products were done by using the SureTag DNA Labeling Kit Purification Columns (Agilent Technologies, Santa Clara, CA). Hybridization was performed at $65^{\circ} \mathrm{C}$ with rotation at $20 \mathrm{rpm}$ for $24 \mathrm{~h}$ after probe denaturation and preannealing with Cot-1 DNA.

The washed array slides were scanned using a DNA microarray scanner (Cat\# G2565BA, Agilent Technologies, Santa Clara, USA). Scanned images of all the COPD patients and control subjects were used for data extraction and image processing was performed by using Feature Extraction software version 10.7.3.1 (Agilent Technologies) and Agilent two-colour microarray protocol [27].

\section{Data Analysis}

The analysis and visualization of array data were performed using CytoGenomics software version 4 (Agilent Technologies, Santa Clara, CA). We used the Aberration Detection Method 1 (ADM-1) algorithm to identify all aberrant intervals in a given sample with consistently high or low log ratios based on a statistical score. This score is computed as the average normalized log ratios of all probes in the genomic interval multiplied by the square root of the number of these probes. It represents the deviation of the average of the normalized log ratios from its expected value of zero. For aCGH analysis according to probes, the thresholds for gains and losses were set at log ratios of 0.3 (gain) and -0.3 (loss), respectively. Thresholds for amplifications were set at $\log$ ratios of 0.8 and thresholds for homozygous deletions were set at -0.8 [28], [29].

\section{RESUlTS}

Chromosomal aberrations like copy number gains, losses, amplifications and deletions were detected by array-based $\mathrm{CGH}$ in samples obtained from patients with COPD $(n=15)$ and from control subjects $(n=13)$. Summary of chromosomal aberrations in subgroups of COPD, viz., COPD smokers $(n=6)$ and COPD ex-smokers $(n=9)$ and of control subjects, viz., control smokers $(n=5)$ and control never smokers $(n=8)$ are shown in Table I.

\begin{tabular}{|c|c|c|c|c|c|}
\hline $\begin{array}{c}\text { Chromosome } \\
\text { Number }\end{array}$ & Cytoband & $\begin{array}{l}\text { Control Smokers } \\
\qquad(\mathrm{n}=5)\end{array}$ & $\begin{array}{c}\text { Control } \\
\text { Never Smokers } \\
(n=8)\end{array}$ & $\begin{array}{c}\text { COPD } \\
\text { Smokers } \\
(n=6)\end{array}$ & $\begin{array}{c}\text { COPD } \\
\text { Ex-smokers } \\
(n=9)\end{array}$ \\
\hline 1 & $\mathrm{q} 21.2$ & $\begin{array}{l}\text { Loss/Gain/ } \\
\text { Deletion }\end{array}$ & $x_{2}$ & C & 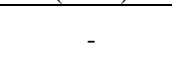 \\
\hline 1 & q31.3 & - & - & $\begin{array}{c}\text { Gain/ } \\
\text { Deletion }\end{array}$ & - \\
\hline 2 & p11.2 & Gain & Gain & Gain & Gain \\
\hline 4 & $\mathrm{q} 13.2$ & $\begin{array}{l}\text { Deletion/ } \\
\text { Loss }\end{array}$ & $\begin{array}{c}\text { Loss/ } \\
\text { Deletion/Gain }\end{array}$ & Deletion/Loss & Loss/ Deletion \\
\hline 8 & $\mathrm{p} 23.1$ & $\begin{array}{c}\text { Loss/ } \\
\text { Deletion }\end{array}$ & Loss & $\begin{array}{c}\text { Loss/ } \\
\text { Deletion }\end{array}$ & Loss/ Deletion \\
\hline 8 & p11.22 & Loss/ Deletion & $\begin{array}{c}\text { Loss/ } \\
\text { Deletion/ } \\
\text { Amplification }\end{array}$ & Loss & $\begin{array}{c}\text { Deletion/ } \\
\text { Amplification }\end{array}$ \\
\hline 10 & q11.22 & Loss & Loss & Loss & - \\
\hline 11 & $\mathrm{p} 15.5$ & Deletion & - & - & $\begin{array}{l}\text { Loss/ } \\
\text { Deletion/ } \\
\text { Gain }\end{array}$ \\
\hline 12 & p13.31 & $\begin{array}{l}\text { Deletion/ } \\
\text { Loss }\end{array}$ & $\begin{array}{l}\text { Deletion/Loss/ } \\
\text { Amplification }\end{array}$ & $\begin{array}{c}\text { Loss/ } \\
\text { Deletion }\end{array}$ & $\begin{array}{c}\text { Deletion/ } \\
\text { Loss/ } \\
\text { Amplification }\end{array}$ \\
\hline 14 & q 11.2 & Loss & Loss & - & Gain/Loss \\
\hline 14 & q32.33 & $\begin{array}{l}\text { Amplification/ } \\
\text { Gain }\end{array}$ & $\begin{array}{l}\text { Amplification/ } \\
\text { Gain/Loss }\end{array}$ & $\begin{array}{c}\text { Gain/ } \\
\text { Amplification }\end{array}$ & $\begin{array}{c}\text { Gain/ } \\
\text { Amplification }\end{array}$ \\
\hline 15 & $\begin{array}{l}\text { q11.1- } \\
\text { q11.2 }\end{array}$ & Loss & - & Loss/Deletion & 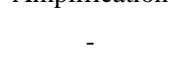 \\
\hline 22 & q11.21 & - & - & - & $\begin{array}{c}\text { Loss/ } \\
\text { Amplification/ } \\
\text { Gain }\end{array}$ \\
\hline$X$ & $\mathrm{q} 28$ & - & - & - & Loss/Gain \\
\hline
\end{tabular}

Chromosomal regions found to be consistently associated with both subgroups of COPD, as well as, of control group were: $2 \mathrm{p} 11.2,4 \mathrm{q} 13.2,8 \mathrm{p} 23.1,8 \mathrm{p} 11.22,12 \mathrm{p} 13.31$ and 14q32.33. Chromosome 2p11.2 showed gain in subgroups of both COPD and control groups. Besides this, copy loss and copy deletion was observed at chromosome $4 \mathrm{q} 13.2$ and 8p23.1 in case of both COPD and control groups. Moreover, chromosome $4 q 13.2$ region showed gain in case of one 
sample of control never smoker (CNS7). Chromosome 8p11.22 region showed loss and deletion in all the subgroups of COPD and controls. However, amplification was also observed at this region in case of one control never smoker (CNS7) and one COPD ex-smoker patient (COPDEx5). Chromosome 12p13.31 region showed loss and deletion in all the subgroups of COPD and controls. Amplification was also observed in one control never smoker (CNS7) and one

COPD ex-smoker patient (COPDEx5), thus showing similar pattern as seen for chromosome, 8p11.22. Amplification and gain was observed at chromosome $14 \mathrm{q} 32.33$ in the subgroups of COPD and controls. Besides amplification and gain, loss was also observed in one control never smoker (CNS8) at this locus. Thus, at all these chromosomes, similar frequency of chromosomal aberrations was observed in case of COPD and controls.

In cases of control samples, the chromosomal changes were mainly in the form of losses and deletion occurred at chromosomes 1q21.2, 10q11.22, 11p15.5, 14q11.2 and 15q11.1-11.2. However, besides loss and deletion, gain was also observed at chromosome 1q21.2 in case of control smokers.

In cases of COPD samples, the chromosomal changes were in the form of losses and deletion at chromosomes 1q31.3, 10q11.22, 11p15.5, 14q11.2, 15q11.1-q11.2, $22 q 11.21$ and Xq28. Gain and amplification was also observed at chromosomes 1q31.3, 11p15.5, 14q11.2, 22q11.21 and Xq28.

We observed copy gains in 2p11.2 region in case of both control smokers and control never smokers, while this region displayed copy gain as well as copy loss in case of both COPD smokers and COPD ex-smokers. Chromosome 10q11.22 showed loss in both control smokers as well as control never smokers. However, in case of COPD, loss at this chromosome was observed only in case of COPD smokers. Similarly, loss was seen at chromosome 14q11.2 in both control smokers and control never smokers. However, both loss and gain was observed at this locus in case of COPD ex-smokers.

We found that the copy loss and deletion of 15q11.1-q11.2 was only detected in case of COPD smokers but not for COPD ex-smokers. We found copy loss of mainly four genes (CHECK2P2, HERC2P3, GOLGA6L6 and GOLGA8CP) at chromosome $15 q 11.1-q 11.2$ in all the samples of COPD smokers implicating that these genes might have roles to play in the pathogenesis of COPD.

Similarly, copy gain and deletion at chromosome 1q31.3 was also detected only for COPD smokers but not for COPD ex-smokers. Thus, this region might be associated with both smoking and COPD. Copy gain at chromosome Xq28 primarily involving four genes, viz. L1CAM, LCA10, AVPR2 and GDI1 was specifically observed in all samples of COPD ex-smokers.

Chromosome 11 p15.5 region showed gain in all the samples of COPD ex-smokers. Two genes KCNQ1 and KCNQOT1 were found to be associated with this region. Besides these genes, two other genes, HOTS and H19 was also found to be associated with loss, deletion and gain at chromosome $11 \mathrm{p} 15.5$ in COPD ex-smokers. Table II provides a summary of differential display in CNVs and corresponding genes associated with these chromosomal regions in different groups.

TABLE II: SUMMARY OF DIFFERENTIAL DISPLAY IN COPY NUMBER VARIATION (CNV) IN DIFFERENT SMOKER GROUPS

\begin{tabular}{|c|c|c|c|c|}
\hline $\begin{array}{l}\text { Groups } \\
\text { (n) }\end{array}$ & $\begin{array}{c}\text { Chromosome } \\
\text { Number }\end{array}$ & Cytoband & $\begin{array}{c}\text { Genes with } \\
\text { Differential } \\
\text { display in CNV }\end{array}$ & Aberrations \\
\hline \multirow{2}{*}{$\begin{array}{l}\text { Control } \\
\text { Smokers } \\
\text { (5) }\end{array}$} & 11 & $\mathrm{p} 15.5$ & $\begin{array}{c}\text { HOTS } \\
\text { H19 }\end{array}$ & $\begin{array}{l}\text { Deletion } \\
\text { Deletion }\end{array}$ \\
\hline & 15 & $\begin{array}{l}\mathrm{q} 11.1- \\
\mathrm{q} 11.2\end{array}$ & $\begin{array}{c}\text { CHECK2P2 } \\
\text { HERC2P2 } \\
\text { GOLGA6L6 } \\
\end{array}$ & $\begin{array}{l}\text { Loss } \\
\text { Loss } \\
\text { Loss } \\
\end{array}$ \\
\hline $\begin{array}{c}\text { COPD } \\
\text { Smokers } \\
(6)\end{array}$ & 15 & $\begin{array}{l}\mathrm{q} 11.1- \\
\mathrm{q} 11.2\end{array}$ & $\begin{array}{c}\text { CHECK2P2 } \\
\text { HERC2P3 } \\
\text { GOLGA6L6 } \\
\text { GOLGA8CP }\end{array}$ & $\begin{array}{l}\text { Loss } \\
\text { Loss } \\
\text { Loss } \\
\text { Loss } \\
\end{array}$ \\
\hline \multirow{2}{*}{$\begin{array}{l}\text { COPD } \\
\text { Ex- } \\
\text { smokers } \\
(9)\end{array}$} & 11 & $\mathrm{p} 15.5$ & $\begin{array}{c}\text { H19 } \\
\text { KCNQ1 } \\
\text { KCNQOT1 }\end{array}$ & $\begin{array}{c}\text { Loss/Deletion/ } \\
\text { Gain } \\
\text { Deletion/ } \\
\text { Loss/Gain } \\
\text { Gain } \\
\text { Gain }\end{array}$ \\
\hline & $\mathrm{X}$ & $\mathrm{q} 28$ & $\begin{array}{c}\text { LICAM } \\
\text { LCA10 } \\
\text { AVPR2 } \\
\text { GDI1 }\end{array}$ & $\begin{array}{l}\text { Gain } \\
\text { Gain } \\
\text { Gain } \\
\text { Gain }\end{array}$ \\
\hline
\end{tabular}

\section{DISCUSSION}

Despite recent advances in COPD genetics, much of the genetic basis of COPD remains unexplained. In the current study, high throughput genome-wide profiling using array CGH has provided an understanding of the nature of genetic susceptibility towards COPD in individuals exposed to cigarette smoke and also helped in identification of the putative candidate genes which might be involved in the pathogenesis of COPD. To the best of our knowledge, this is the first study relating to whole genome copy number variations (CNVs) in current and ex-smoker COPD patients. Chromosomal loci and the candidate genes identified by previous Genome-wide Association Studies (GWAS) found to be associated with COPD were: 15q25 (CHRNA3/5), 4q31 (HHIP, GYPA), 6p21 (BAT3/AGER), 5q33 (HTR4), 15q11 (SNRPN), 1q21 (CRP/IL6R) and 4q24 (GSTCD) [30], [31]. However, many of these loci identified in GWAS are yet to be functionally explained.

In the present study, copy loss of mainly four genes at chromosome 15q11.1-q11.2 was observed in all the samples of COPD smokers. These were: Checkpoint Kinase 2 Pseudogene 2 (CHEK2P2), Hect Domain and RLD 2 Pseudogene 3 (HERC2P3), Golgin A6 Family Like 6 (GOLGA6L6) and Golgin A8 Family Member C, Pseudogene (GOLGA8CP). Of these genes at chromosome 15q11.1-q11.2, three genes namely CHEK2P2, HERC2P2 and GOLGA6L6 were observed to be associated with CNVs in Control smokers as well. In a recent study, CHEK2P2 was identified as a novel lung cancer metastasis-associated gene [32]. Gao et al. revealed by integrating mRNA, miRNA and long non-coding RNA (lncRNA) profiles that lncRNA CHEK2P2 was predicted as a central node correlating to multiple genes associated with laryngeal squamous cell carcinoma with lymph node metastasis [33].

Furthermore, there is a cluster of low copy DNA repeats located within chromosome region 15q11.2-q13.1. These 
low copy repeat sequences are called duplicons and contain pseudogenes [34]. Duplicons found within breakpoints BP1, BP2 and BP3 have been characterized by the presence of the HERC2 gene (at BP3) and HERC2 pseudogenes (at BP1 and $\mathrm{BP} 2$ ) [35]. Interestingly, HERC2P3 plays a critical role in the cell growth and migration in human gastric cancer cells [36]. HERC2 is 97.1, 97.3, 97.2 and $95.0 \%$ identical to HERC2P1, HERC2P2, HERC2P3 and HERC2P4, respectively, while HERC2P1-P3 are 99.3-99.6\% identical to each other [36]. Previous GWASs revealed that $15 q 25.1$ region bears linkage with smoking [37] and is associated with lung cancer [38]. As smoking is a risk factor for both COPD and lung cancer, the association of this locus with COPD and lung cancer might be mediated through smoking [39]. Chromosome 15q25.1 locus contains nicotinic receptors and this region also showed similarities with regions $15 q 11-q 13$ and $15 q 24$ on the basis of a low copy repeat sequence (LCR15) [35]. Thus, it appears that copy loss at chromosome 15q11.1-q11.2 observed in Control smokers and COPD smokers may be putatively associated with the development of smoking linked cancer in the lung.

In the present study, copy gain at chromosome Xq28 was observed only in COPD ex-smokers. Four genes, namely L1 Cell Adhesion Molecule (L1CAM), Lung CarcinomaAssociated 10 (LCA10), Arginine Vasopressin Receptor 2 (AVPR2) and GDP Dissociation Inhibitor 1 (GDI1) were found to be associated with copy gain in all the samples of COPD ex-smokers. Duplications within the chromosome $\mathrm{Xq} 28$ band are the most common CNVs discovered in males with X-linked intellectual deficiency (XLID) [40]. GDI1 gene plays critical role in normal neurological development [41]-[43]. Elevated GDI1 mRNA expression is positively correlated with the likelihood of developing epilepsy and severity of intellectual deficiency [44], [45]. However, its association with COPD and smoking is being reported for the first time. Mutations in GDI1 may also influence the actin cytoskeleton [46]. Whether copy number gain in GDI1 plays any role in skeletal muscle dysfunction characterised by decreased muscle strength, endurance and exercise intolerance observed in COPD remains only as a conjecture at this point of time [47]-[49].

In the present study, copy number gain of L1CAM gene at chromosome Xq28 was observed in COPD ex-smokers. L1CAM plays an important role in Epithelial Mesenchymal Transition (EMT) and is associated with poor prognosis in resected non-small cell lung cancer patients [50], [51]. As L1CAM gene plays role in the development of cancers, it may be conjectured that COPD ex-smokers are susceptible to development of cancer even after the cessation of smoking. Additionally, copy number gain of AVPR2 gene at chromosome Xq28 was observed in COPD ex-smokers. The pathophysiological significance of involvement of Arginine Vasopressin Receptor 2 (AVPR2) in COPD ex-smokers is only conjectural at this point of time. Interestingly, elevated levels of circulating Arginine Vasopressin (AVP) and proAVP are predictors of mortality in COPD patients in the stable state and also during exacerbations [52]. It is possible that elevated levels of arginine vasopressin along with higher level of its receptors may have a role to play in development of oedema in COPD patients [53], [54].
Furthermore, copy gain, amplification and loss at chromosome 22q11.21 was observed only in COPD exsmokers. Glutathione S-transferase theta 1 (GSTT1) is located in chromosome 22q11.21 region. The GST enzyme is implicated in the metabolism of exogenous toxic substrates, detoxification of carcinogens present in tobacco smoke and they also exhibit peroxidase activity, and thus the enzyme may play an important role in oxidative stress defense [55]. It is speculated that this enzyme may play a protective role in COPD ex-smokers thereby protecting the lungs by antagonizing systemic oxidative stress and alleviating inflammation within the lungs [56]. Previous reports have suggested an association between the deficiency in antioxidative and detoxifying GST gene and poorer lung function in smokers and patients with respiratory diseases [57], [58]. Further, this enzyme shows a high degree of polymorphisms and is closely associated with the occurrence and development of COPD [59], [60]. Epidemiological studies have indicated that GSTT1 polymorphisms and deficiency of GSTT1 activity are associated with increased risk for different cancers among smokers [56]. Imboden et al. reported that impact of the GSTT1 genotype on different lung functions parameters depended on the smoking status [57]. The strength of the GSTT1 association with FVC and $\mathrm{FEF}_{25-75}$ in fact differed between never smokers and persistent smokers [57], [61].

To our knowledge, this is the first study reporting genes (GOLGA6 and GOLGA8) in chromosomes 1 and 15 encoding golgin protein family were affected in COPD smokers. The golgins are a family of predominantly coiledcoil proteins that are anchored to the Golgi membrane presumably for tethering of nearby membranes and cytoskeletal elements required for vesicular traffic at the Golgi apparatus, the maintenance of Golgi architecture, as well as the positioning of the Golgi apparatus within cells [62]. These genes are found in duplicons having more than $90 \%$ similarity and are associated with deletions, inversions and other chromosome rearrangements that underlie several genomic disease (https://www.genecards.org/). For example, recurrent chromosome 1q13.3 microdeletions are promoted by palindromic GOLGA8 core duplicons and are known to be associated with autism, intellectual disability, epilepsy and schizophrenia [63]. Further studies are necessary to unravel the pathophysiological significance of these genes with smoking and COPD.

In the present study, deletion of H19 Opposite Tumor Suppressor (HOTS) and H19 Imprinted Maternally Expressed Transcript (H19) gene was seen at chromosome 11 p15.5 in control smokers. These genes possess oncogenic potential and also have a role in EMT [64]. These genes also showed gain in case of COPD ex-smokers. It appears possible that the over-expression of these genes in COPD exsmokers turn them susceptible to cancer. It is also speculated that the gain of H19 in COPD ex-smokers might have a role to play with their quality of life as it has been reported that increased expression of this gene is involved in loss of muscle mass and strength in COPD patients. Moreover, it was also observed that increased expression of H19 and altered methylation of the H19 imprinting control region were found to be associated with a low fat free mass index (FFMI) in COPD patients. Thus, it also suggests that 
epigenetic control of this H19 loci may contribute to a susceptibility to a low FFMI in COPD patients [65].

In the present study we have observed gain at chromosome 11 p15.5 in case of COPD ex-smokers and an important gene associated with this region is Potassium Voltage-Gated Channel Subfamily Q Member 1 (KCNQ1). This genes may function as tumor suppressor [66], and might have a role to play in protection of COPD ex-smokers from development of cancer after smoking cessation. SNPs in KCNQ1 are mainly associated with susceptibility to type 2 diabetes [67]. Tobacco smoking is associated with differential DNA methylation of KCNQ1 [68]. Studies suggest a beneficial effect of smoking cessation on DNA methylation at this risk loci [68], [69]. It may return to levels similar to never smokers at some sites, while other sites stay differentially methylated. Potassium channels may play role in the pathogenesis, progression and exacerbation of COPD. Modulation of these channels may cause reduction in cough and mucus production, inhibition in airway inflammation and remodelling and may also produce beneficial effects such as bronchodilation and cause a reduction in airways hyperresponsiveness [70], [71]. Potassium channels modulators has been suggested to be a useful treatment option in COPD [70], [72].

In conclusion, array CGH performed in the present study to detect copy number variations of genetic loci revealed a few 'hot genes' associated with COPD. Chromosomal regions found associated with COPD were 11p15.5, 15q11.1q11.2 and Xq28, which home several genes, viz.CHECK2P2, HERC2P3, GOLGA6L6 and GOLGA8CP associated with COPD smokers, and LICAM, LCA10, AVPR2, GDI1, HOTS and H19 associated with COPD ex-smokers. These genes and loci can be further explored for their potential use as predictive markers, and may provide novel understanding of pathophysiological basis of COPD and result in triggering new research leads in the management and treatment of COPD. Future studies including combined analysis of aCGH data and microarray gene expression data may help in unravelling the genomic basis of pathogenesis of COPD.

\section{ACKNOWLEDGMENT}

The study was funded by Department of Science and Technology (DST), India.

\section{REFERENCES}

[1] Raherison C, Girodet P-O. "Epidemiology of COPD," Eur Respir Rev, vol. 18 , pp. 213-21, Dec 2009.

[2] Soriano JB, Agusti A. "The graphic of COPD: or balancing repair (yang) and inflammation (yin)," Eur Respir J, vol. 32, pp. 1426-7, Dec 2008.

[3] Spurzem MJR, Rennard MSI, Spurzem MJR, Rennard MSI, Jay. "Pathogenesis of COPD," Semin Respir Crit Care Med, vol. 26, pp. 142-53, Apr 2006.

[4] Laniado-Laborín R. "Smoking and Chronic Obstructive Pulmonary Disease (COPD). Parallel Epidemics of the 21st Century," Int J Environ Res Public Health, vol. 6, pp. 209-24, Jan 2009.

[5] Zeng G, Sun B, Zhong N. "Non-smoking-related chronic obstructive pulmonary disease: a neglected entity?," Respirol Carlton Vic, vol. 17, pp. 908-12, Aug 2012.

[6] Larson RK, Barman ML, Kueppers F. "Genetic and Environmental Determinants of Chronic Obstructive Pulmonary Disease," Ann Intern Med, vol. 72, pp. 627-32, May 1970.
[7] Tager IB, Rosner B, Tishler PV, Speizer FE, Kass EH. "Household aggregation of pulmonary function and chronic bronchitis," Am Rev Respir Dis, vol. 114, pp. 485-92, Sep 1976.

[8] Seifart C, Plagens A. "Genetics of chronic obstructive pulmonary disease," Int J Chron Obstruct Pulmon Dis, vol. 2, pp. 541-550, Dec 2007.

[9] Li LSK, Paquet C, Johnston K, Williams MT. "What are my chances of developing COPD if one of my parents has the disease?" A systematic review and meta-analysis of prevalence of co-occurrence of COPD diagnosis in parents and offspring," Int J Chron Obstruct Pulmon Dis, vol. 12, pp. 403-15, Jan 2017.

[10] Stolk J, Seersholm N, Kalsheker N. "Alpha1-antitrypsin deficiency: current perspective on research, diagnosis, and management," Int J Chron Obstruct Pulmon Dis, vol. 1, pp-151-60, Jun 2006.

[11] Bashir A, Shah NN, Hazari YM, Habib M, Bashir S, Hilal N, et al. "Novel variants of SERPIN1A gene: Interplay between alpha1antitrypsin deficiency and chronic obstructive pulmonary disease," Respir Med, vol. 117, pp. 139-49, Aug 2016.

[12] Givelber RJ, Couropmitree NN, Gottlieb DJ, Evans JC, Levy D, Myers $\mathrm{RH}$, et al. "Segregation Analysis of Pulmonary Function among Families in the Framingham Study," Am J Respir Crit Care Med, vol. 157, pp. 1445-51, May 1998.

[13] Ionita-Laza I, Rogers AJ, Lange C, Raby BA, Lee C. "Genetic association analysis of copy number variation (CNVs) in human disease pathogenesis," Genomics, vol. 93, pp. 22-6, Jan 2009.

[14] Scherer SW, Lee C, Birney E, Altshuler DM, Eichler EE, Carter NP, et al. "Challenges and standards in integrating surveys of structural variation," Nat Genet, vol. 39, pp. S7-15, Jul 2007.

[15] Hovhannisyan G, Harutyunyan T, Aroutiounian R, Liehr T. "DNA Copy Number Variations as Markers of Mutagenic Impact," Int J Mol Sci, vol. 20, pp. 4723, Oct 2019.

[16] Choy KW, Setlur SR, Lee C, Lau TK. "The impact of human copy number variation on a new era of genetic testing," BJOG Int J Obstet Gynaecol, vol. 117, pp. 391-8, Feb 2010.

[17] Freeman JL. "Copy number variation: New insights in genome diversity," Genome Res, vol. 16, pp. 949-61, Jun 2006.

[18] Tuzun E, Sharp AJ, Bailey JA, Kaul R, Morrison VA, Pertz LM, et al. "Fine-scale structural variation of the human genome," Nat Genet, vol. 37, pp. 727-32, Jul 2005.

[19] Russo CD, Di Giacomo G, Cignini P, Padula F, Mangiafico L, Mesoraca A, et al. "Comparative study of aCGH and Next Generation Sequencing (NGS) for chromosomal microdeletion and microduplication screening," J Prenat Med, vol. 8, pp. 57-69, Apr 2014.

[20] Lucito R, Healy J, Alexander J, Reiner A, Esposito D, Chi M, et al. "Representational Oligonucleotide Microarray Analysis: A HighResolution Method to Detect Genome Copy Number Variation," Genome Res, vol. 13, pp. 2291-305, Oct 2003.

[21] Dawson AJ, Yanofsky R, Vallente R, Bal S, Schroedter I, Liang L, et al. "Array comparative genomic hybridization and cytogenetic analysis in pediatric acute leukemias," Curr Oncol, vol. 18, pp. e210, Oct 2011.

[22] Gullotta F, Biancolella M, Costa E, Colapietro I, Nardone AM, Molinaro P, et al. "Prenatal diagnosis of genomic disorders and chromosome abnormalities using array-based comparative genomic hybridization," J Prenat Med, vol. 1, pp. 16-22, Jan 2007.

[23] Gao J, Liu C, Yao F, Hao N, Zhou J, Zhou Q, et al. "Array-based comparative genomic hybridization is more informative than conventional karyotyping and fluorescence in situ hybridization in the analysis of first-trimester spontaneous abortion," Mol Cytogenet, vol. 5, pp. 33, Jul 2012.

[24] Coughlin CR, Scharer GH, Shaikh TH. "Clinical impact of copy number variation analysis using high-resolution microarray technologies: advantages, limitations and concerns," Genome Med, vol. 4, pp. 1-12, Oct 2012.

[25] Nowakowska B. "Clinical interpretation of copy number variants in the human genome," J Appl Genet, vol. 58, pp. 449-57, Nov 2017.

[26] Choi JS, Lee WJ, Baik SH, Yoon HK, Lee K-H, Kim YH, et al. "Array CGH Reveals Genomic Aberrations in Human Emphysema," Lung, vol. 187, pp. 165-72, Jun 2009.

[27] https://www.agilent.com/cs/library/usermanuals/public/G441090020_CGH_ULS_3.5.pdf.

[28] Boelens MC, Gustafson AM, Postma DS, Kok K, van der Vries G, van der Vlies $\mathrm{P}$, et al. "A chronic obstructive pulmonary disease related signature in squamous cell lung cancer," Lung Cancer, vol. 72, pp. 177-83, May 2011.

[29] Hua L, Yang Z, Zhou P, An L. "Using Comparative Genomic Hybridization Arrays (aCGH) Techniques to Detect Chronic Obstructive Pulmonary Disease Related Susceptibility Regions," International Journal of Bio-Science and Bio-Technology, vol. 5, pp. 121-130, Jan 2013. 
[30] Hobbs BD, de Jong K, Lamontagne M, Bossé Y, Shrine N, Artigas MS, et al. "Genetic loci associated with chronic obstructive pulmonary disease overlap with loci for lung function and pulmonary fibrosis," Nat Genet, vol. 49, pp. 426-32, Mar 2017.

[31] Wain LV, Shrine N, Artigas MS, Erzurumluoglu AM, Noyvert B, Bossini-Castillo L, et al. "Genome-wide association analyses for lung function and chronic obstructive pulmonary disease identify new loci and potential druggable targets," Nat Genet, vol. 49, pp. 416-25, Mar 2017.

[32] Aljohani HM, Aittaleb M, Furgason JM, Amaya P, Deeb A, Chalmers $\mathrm{JJ}$, et al. "Genetic mutations associated with lung cancer metastasis to the brain," Mutagenesis, vol. 33, pp. 137-45, Apr 2018.

[33] Gao W, Zhang C, Ma T, Wen S, Fu R, Zhao D, et al. "Potential biomarkers and their regulatory relationships in laryngeal squamous cell carcinoma with lymph node metastasis revealed by integrating mRNA, microRNA and long non-coding RNA profiles," Int J Clin Exp Pathol, vol, 9, pp. 5103-16, May 2016.

[34] Eichler EE. "Masquerading repeats: paralogous pitfalls of the human genome," Genome Res, vol. 8, pp. 758-62, Aug 1998.

[35] Pujana MA, Nadal M, Gratacòs M, Peral B, Csiszar K, GonzálezSarmiento R, et al. "Additional Complexity on Human Chromosome 15q: Identification of a Set of Newly Recognized Duplicons (LCR15) on 15q11-q13, 15q24, and 15q26," Genome Res, vol.11, pp. 98-111, Jan 2001.

[36] Chen J, Cai H, Xie Y, Jiang H. "Targeting long non-coding RNA HERC2P3 inhibits cell growth and migration in human gastric cancer cells," International Journal of Clinical and Experimental Pathology, vol. 10, pp. 7632-9, Jul 2017.

[37] Liu JZ, Tozzi F, Waterworth DM, Pillai SG, Muglia P, Middleton L, et al. "Meta-analysis and imputation refines the association of $15 \mathrm{q} 25$ with smoking quantity," Nat Genet, vol. 42, pp. 436-40, May 2010.

[38] Hung RJ, McKay JD, Gaborieau V, Boffetta P, Hashibe M, Zaridze D, et al. "A susceptibility locus for lung cancer maps to nicotinic acetylcholine receptor subunit genes on 15q25," Nature, vol. 452, pp. 633-7, Apr 2008.

[39] Nedeljkovic I, Terzikhan N, Vonk JM, van der Plaat DA, Lahousse L, van Diemen CC, et al. "A Genome-Wide Linkage Study for Chronic Obstructive Pulmonary Disease in a Dutch Genetic Isolate Identifies Novel Rare Candidate Variants," Front Genet, vol. 9, pp. 133, Apr 2018.

[40] El-Hattab AW, Schaaf CP, Fang P, Roeder E, Kimonis VE, Church JA, et al. "Clinical characterization of int22h1/int22h2-mediated Xq28 duplication/deletion: new cases and literature review," BMC Med Genet, vol. 16, pp. 1-12, Dec 2015.

[41] Bianchi V, Farisello P, Baldelli P, Meskenaite V, Milanese M, Vecellio M, et al. "Cognitive impairment in Gdi1-deficient mice is associated with altered synaptic vesicle pools and short-term synaptic plasticity, and can be corrected by appropriate learning training," Hum Mol Genet, vol. 18, pp. 105-17, Jan 2009.

[42] Yamamoto T, Shimojima K, Shimada S, Yokochi K, Yoshitomi S, Yanagihara K, et al. "Clinical impacts of genomic copy number gains at Xq28," Hum Genome Var, vol. 1, pp. 1-6, July 2014.

[43] Vanmarsenille L, Giannandrea M, Fieremans N, Verbeeck J, Belet S, Raynaud M, et al. "Increased dosage of RAB39B affects neuronal development and could explain the cognitive impairment in male patients with distal Xq28 copy number gains," Hum Mutat, vol. 35, pp. 377-83, Mar 2014.

[44] Vandewalle J, Van Esch H, Govaerts K, Verbeeck J, Zweier C, Madrigal I, et al. "Dosage-dependent severity of the phenotype in patients with mental retardation due to a recurrent copy-number gain at Xq28 mediated by an unusual recombination," Am J Hum Genet, vol. 85, pp. 809-22, Dec 2009.

[45] Ward DI, Buckley BA, Leon E, Diaz J, Galegos MF, Hofherr S, et al. "Intellectual disability and epilepsy due to the K/L-mediated Xq28 duplication: Further evidence of a distinct, dosage-dependent phenotype," Am J Med Genet A, vol. 176, pp. 551-9, Mar 2018.

[46] Rivero F, Illenberger D, Somesh BP, Dislich H, Adam N, Meyer A-K. "Defects in cytokinesis, actin reorganization and the contractile vacuole in cells deficient in RhoGDI," EMBO J, vol. 21, pp. 4539-49, Sep 2002.

[47] Wüst RC, Degens H. "Factors contributing to muscle wasting and dysfunction in COPD patients," Int J Chron Obstruct Pulmon Dis, vol. 2, pp. 289-300, Sep 2007.

[48] Kim HC, Mofarrahi M, Hussain SN. "Skeletal muscle dysfunction in patients with chronic obstructive pulmonary disease," Int J Chron Obstruct Pulmon Dis, vol. 3, pp. 637-58, Dec 2008.

[49] Jaitovich A, Barreiro E. "Skeletal Muscle Dysfunction in Chronic Obstructive Pulmonary Disease. What We Know and Can Do for Our Patients," Am J Respir Crit Care Med, vol. 198, pp. 175-86, Jul 2018.
[50] Chen J, Gao F, Liu N. "L1CAM promotes epithelial to mesenchymal transition and formation of cancer initiating cells in human endometrial cancer," Exp Ther Med, vol. 15, pp. 2792-7, Mar 2018

[51] Yu H, Zhou P, Li D, Li W. "L1CAM-positive expression is associated with poorer survival outcomes in resected non-small cell lung cancer patients," Int J Clin Exp Pathol, vol. 12, pp. 2665-72, Jul 2019.

[52] Stolz D, Meyer A, Rakic J, Boeck L, Scherr A, Tamm M. "Mortality risk prediction in COPD by a prognostic biomarker panel," Eur Respir J, vol. 44, pp. 1557-70, Dec 2014.

[53] de Leeuw PW, Dees A. "Fluid homeostasis in chronic obstructive lung disease," Eur Respir J, vol. 22, pp. 33s-40s, Nov 2003.

[54] Sarkar M, Bhardwaz R, Madabhavi I, Modi M. "Physical signs in patients with chronic obstructive pulmonary disease," Lung India Off Organ Indian Chest Soc, vol. 36, pp. 38-47, Feb 2019.

[55] Dasari S, Ganjayi MS, Meriga B. "Glutathione S-transferase is a good biomarker in acrylamide induced neurotoxicity and genotoxicity," Interdiscip Toxicol, vol. 11, pp. 115-21, Aug 2018.

[56] Yuan C, Chang D, Lu G, Deng X. "Genetic polymorphism and chronic obstructive pulmonary disease," Int J Chron Obstruct Pulmon Dis, vol. 12, pp. 1385-93, May 2017.

[57] Imboden M, Downs SH, Senn O, Matyas G, Brändli O, Russi EW, et al. "Glutathione $S$-transferase genotypes modify lung function decline in the general population: SAPALDIA cohort study," Respir Res, vol. 8, Jan 2007.

[58] Rogers AJ, Brasch-Andersen C, Ionita-Laza I, Murphy A, Sharma S, Klanderman BJ, et al. "The interaction of glutathione S-transferase M1-null variants with tobacco smoke exposure and the development of childhood asthma," Clin Exp Allergy J Br Soc Allergy Clin Immunol," vol. 39, pp. 1721-9, Nov 2009.

[59] Dey T, Gogoi K, Unni BG, Kalita M, Bharadwaz M, Bhattacharjee M, et al. "Role of Glutathione S Transferase Polymorphism in COPD with Special Reference to Peoples Living in the Vicinity of the Open Cast Coal Mine of Assam," PLoS ONE, vol. 9, pp. e96739, May 2014.

[60] Cao T, Xu N, Wang Z, Liu H. "Effects of Glutathione S-Transferase Gene Polymorphisms and Antioxidant Capacity per Unit Albumin on the Pathogenesis of Chronic Obstructive Pulmonary Disease," Oxid Med Cell Longev, vol. 2017, Aug 2017.

[61] Kim S-J, Kim M-G, Kim K-S, Song J-S, Yim S-V, Chung J-H. "Impact of Glutathione S-Transferase M1 and T1 Gene Polymorphisms on the Smoking-Related Coronary Artery Disease," J Korean Med Sci, vol. 23, pp. 365-72, Jun 2008.

[62] Witkos TM, Lowe M. "The Golgin Family of Coiled-Coil Tethering Proteins," Front Cell Dev Biol, vol. 3, pp. 86, Jan 2016.

[63] Antonacci F, Dennis MY, Huddleston J, Sudmant PH, Steinberg KM, Rosenfeld JA, et al. "Palindromic GOLGA8 core duplicons promote chromosome 15q13.3 microdeletion and evolutionary instability," Nat Genet, vol. 46, pp. 1293-302, Dec 2014.

[64] Matouk IJ, Halle D, Gilon M, Hochberg A. "The non-coding RNAs of the H19-IGF2 imprinted loci: A focus on biological roles and therapeutic potential in Lung Cancer," J Transl Med, vol. 13, pp. 113, Apr 2015.

[65] Lewis A, Lee JY, Donaldson AV, Natanek SA, Vaidyanathan S, Man WD -C., et al. "Increased expression of H19/miR-675 is associated with a low fat-free mass index in patients with COPD," J Cachexia Sarcopenia Muscle, vol. 7, pp. 330-44, Jun 2016.

[66] Than BLN, Goos JACM, Sarver AL, O’Sullivan MG, Rod A, Starr $\mathrm{TK}$, et al. "The role of KCNQ1 in mouse and human gastrointestinal cancers," Oncogene, vol. 33, pp. 3861-8, Jul 2014.

[67] Unoki H, Takahashi A, Kawaguchi T, Hara K, Horikoshi M, Andersen G, et al. "SNPs in KCNQ1 are associated with susceptibility to type 2 diabetes in East Asian and European populations," Nat Genet, vol. 40 pp. 1098-102, Sep 2008.

[68] Ligthart S, Steenaard RV, Peters MJ, van Meurs JBJ, Sijbrands EJG Uitterlinden AG, et al. "Tobacco smoking is associated with DNA methylation of diabetes susceptibility genes," Diabetologia, vol. 59, pp. 998-1006, Jan 2016.

[69] Tsaprouni LG, Yang T-P, Bell J, Dick KJ, Kanoni S, Nisbet J, et al. "Cigarette smoking reduces DNA methylation levels at multiple genomic loci but the effect is partially reversible upon cessation," Epigenetics, vol. 9, pp. 1382-96, Oct 2014.

[70] Bartoszewski R, Matalon S, Collawn JF. "Ion channels of the lung and their role in disease pathogenesis," Am J Physiol - Lung Cell Mol Physiol, vol. 313, pp. L859-72, Nov 2017.

[71] Malerba M, Montuschi P, Radaeli A, Pirisi M. "Role of beta-blockers in patients with COPD: current perspective," Drug Discov Today, vol. 20, pp. 129-35, Jan 2015.

[72] Pelaia G, Vatrella A, Busceti MT, Gallelli L, Calabrese C, Terracciano $\mathrm{R}$, et al. "Cellular Mechanisms Underlying Eosinophilic and Neutrophilic Airway Inflammation in Asthma," Mediators Inflamm, vol. 2015, Mar 2015. 